\title{
REBORN POLAND OR RECONSTRUCTED EMPIRE? QUESTIONS ON THE COURSE AND RESULTS OF POLISH EASTERN POLICY (1918-1921)
}

\author{
Andrzej Nowak
}

\begin{abstract}
The article presents the main geopolitical concepts of Polish foreign politics and military strategy between 1918 and 1921. The author discusses two general programmes of policy towards Poland's neighbours to the East: the 'federalist' option associated with Józef Pitsudski, and the 'incorporationist' option of Roman Dmowski. The analysis is concentrated around the efforts to realize the former programme. Starting from a detailed analysis of Pitsudski's instructions to the Polish delegation to the Paris Peace Conference at the end of 1918, through a special mission of Michat Römer sent to Lithuania in April 1919, and reasons of its failure, the author turns to a history of the 'Ukrainian card', played by Pitsudski in 1919 and 1920 in order to achieve a geopolitical counter-balance to any Russian/Soviet imperialism. Finally, the article deals with the meaning of the Pitsudski's eastern policy as one of the main factors which stopped the westward drive of Soviet Russia for the next 20 years.
\end{abstract}

A ghost haunted nineteenth-century Europe - the ghost of the Polish Commonwealth: a great country, with a centuries-old tradition of statehood within more or less stable borders, although borders that would constantly and gradually be cut out in the East. The borders from the year 1772, that is from before the first partition, were strongly ingrained in the historical consciousness of not only the country's citizens or their heirs, but equally in the memory of the political elites of the great powers that carried out the partitions and benefited from them.

Through an unprecedented act the Commonwealth was erased from the map of the continent at the moment when her elites had already undertaken - as the first political community in Central and Eastern Europe - to construct a modern nation. Yet what nation precisely? A Polish nation, naturally. One that would write and speak the Polish language (as proved by textbooks prepared by the Commission of National Education), and would be less decentralized politically than before (the Constitution of May 3, 1791 made no reference 
to Lithuania). Should Poland have survived the European crises at the end of the eighteenth century, and continued to implement the programme of modernization, it would have to face, sooner or later, the great tensions rooted in those very matters: the language of education, administration, army - the three institutions, which in other nineteenth-century states were turning 'peasants into French', or into Germans, or Italians... Under the partitions, the birth of new national projects, competing with the Polish efforts on the territories of the former Commonwealth, run in parallel to yet a different phenomenon: a more or less systematic attempts by the administrations of the partitioning powers, to 'de-Polonize' the territories under their control, to weaken the still-dominant Polish cultural and economic elements - in order to strengthen control over them by the imperial centre, which was founded on much different cultural and ethnic substrata: Russian and German. The competition between the new masters and the legacy of the former ones, allowed the national programmes of the ethnic inhabitants of those territories to come to maturity, particularly the Lithuanian and Ukrainian ones, but also Belarusian. On the other hand, in the process of modernizing and educating - in the sphere of politics as well - the 'masses', formerly passive in their public life, the Polish elements were moving westward, beyond the 1772 borders, onto the territories long-lost by the Polish state to her western, German-speaking neighbours - onto Pomerania and Silesia.

Bound by historical obligation in the form of pre-partition borders, by the consequences of the de-Polonization policies pursued for over a century by the partitioning powers (with the exception of Austro-Hungary in the post-1866 period), and finally by the realities springing from the changes in the concept of a nation - as the legitimizing fundament for creating and shaping the statehood - the new 'mental map' of Poland would be constructed at the turn of the nineteenth century. A map with vague contours.

The real map of the reconstructed Polish Republic was the result of struggles. The primary forces in that struggle were the geopolitical successors to the partitioning powers: Soviet Russia (for a time 'White' Russia as well) and Germany. Partaking in that struggle were also those forces, which supported the political-national programmes competing with the Polish one on the eastern borderlands of the former Commonwealth: Ukrainian, Lithuanian and, the weakest of them, the Belarusian programme. A significant 
influence on the events and the results of that struggle was exerted by the western powers, victors of World War One - mainly Great Britain and France, and to a lesser extent the United States - which nourished the ambitions of dictating the new European order founded on the compromise between the proclaimed principles (the right of nations to self-determination) and their own strategic and economic interests. Quite naturally, Polish society was a party to that struggle, with its choices and determination, with the competing (yet at the same time - a fact to remember - essentially convergent in their aims) political programmes and visions of the reconstructed Poland, and foremost with the Polish army, which, through its 'spirit' and organization, was the key to those programmes being either implemented or, conversely, remaining unfulfilled.

The decisive phase of that very struggle began, when the three empires, partakers to the partitions and guardians of its results, came down on each other in conflict and revolution. It has been a long time that Poland, or rather the political forces representing it, have been preparing for that very moment, and in effect did not waste the time in their efforts, which bore fruits in the fall of 1918. Pursuing policies directed at both the Entente and the Central Powers, brought results - good and bad ones. Since 1916, the territories of the Polish Kingdom remaining in German and Austro-Hungarian domains, saw the creation of a legal Polish administration, police and army. Policies pursued with respect to the Entente furnished the Polish question with a diplomatic representation to the finally victorious powers, but equally with the military units recreated under their auspices: in France and Russia. On the other hand, at the moment the conflict was over and the 'Polish question' entered its critical phase - when the shape and the borders of the reconstructed statehood were to be decided - the pursuit of both directions during the war resulted in Poland not having a single programme or a single representation. This bore heavily on the issues related to the borders and the nature of Poland's relations with its neighbours to the east.

Yet before any final settlement of those issues was made, the more pressing matter concerned the ending of Austro-German occupation of the country, reaching an agreement on the evacuation of the nearly half a million German soldiers from Ukraine, Belarus and Lithuania in such a manner, as to not risk a catastrophe for young Polish statehood, and further on - to establish a single government, a uniform administration and an army, all three of which would 
be recognized by the whole society, as well as by the victorious western powers. That very task was accomplished. The surprisingly quick organizational success was founded on the broad social support for the rebuilding of Polish statehood, on the very will to fight for that statehood, the will expressed through the popular act of disarming German and Austrian military posts and garrisons taking place at the end of October and early in November 1918. Yet an analogous will characterized also Poland's new (in the political sense) neighbours - Ukrainians, Lithuanians, Czechs. This in turn arose the immediate question of whether the relations between them, and the natural frictions related to the delineation of their borders, would be settled through a compromise - or force.

When the phantom of Pax Germanica in Central and Eastern Europe began to fade with the inescapable defeat of Germany at the end of October 1918, the answer to this question was being given through faits accomplis. The first to arise was the PolishCzechoslovakian conflict (or more precisely Polish-Czech conflict) over Teschen Silesia. On January 23, 1919, the Czechoslovak army resolved the conflict militarily (the majority of the Polish armed forces were at the time engaged in eastern Galicia fighting the Ukrainians). Czech diplomacy proved itself patient and effective in the efforts to assure recognition for the military achievements. It waited for the proper moment, when in July 1920, pressed by the Soviet offensive, Poland had to turn to the Entente powers for help. In return for the promise of such help, the Polish Prime Minister, Władysław Grabski, consented at the Spa Conference on July 10, 1920 to the decisions unfavourable for Poland, by the High Council of the Entente, to partition the Teschen Silesia region. The struggle for its southern border was thus lost by Poland. Yet equally, it marked a loss for Czechoslovakia. The cooperation between Poland and Czechoslovakia, with its high geopolitical rationale, was ruined at the very beginning of those countries' newly gained independence, by the relentless position of the politicians in Prague, precluding any compromise whatsoever. The very position dictated that Czechoslovakia take advantage of the deadly threat to the independence of its neighbour to the north in the summer of 1920, as long as it could cut out the desired part of Poland's territory. Thus, instead of cooperation, the year 1938 witnessed a sad revenge by Poland... ${ }^{1}$

${ }^{1}$ For the best summary of the Polish-Czechoslovak conflict 1918-1921 see M.K. Kamiński, Konflikt polsko-czeski 1918-1921 (Warsaw, 2001). 
Yet why did Prague's territorial aspirations find support among Entente's leaders, while the arguments conveyed by Warsaw, although founded in that case on the principle of the popular will of the inhabitants of those territories, were rejected by the western powers in 1920? One of the crucial reasons for such an approach, a reason that had a negative effect on the efforts of the Polish diplomacy with respect not only to those territories disputed by Czechoslovakia, lay in the conviction that an attempt at giving substance to the ghost of the Polish Commonwealth, was bound to collide with the very fundaments of the geopolitical 'order' in Eastern Europe, to which the political imagination of European elites was accustomed - also the elites in those western powers, which came to reject that 'order' in the course of World War One. However, the Czechoslovak state was built on the ruins of the Habsburg monarchy, the collapse of which was fully accepted by the victor powers. The potential revanchism of Austria, or (although a graver problem itself) of Hungary - was not treated as serious reason for concern. Yet Poland was to be recreated primarily at the expense of both Germany and imperial Russia.

Could a lasting international order be established in Europe, if Germany and Russia were to be removed from participating in it if both of those powers would be determined to eradicate that very order? This was the question asked by the leaders of the victorious powers, and also, post factum, by the historians of diplomacy of that time. As one of the key reasons behind the failure of the Versailles system, the latter most often point to 'voracious Polish appetites', 'Polish imperialism'. Poland 'took' too much. 'Took' from whom? Naturally - from Germany and Russia (already Soviet), thus making the Versailles Treaty unacceptable for both, causing them to bring about its collapse. Such is the 'verdict' given by, among others, Henry Kissinger and George Kennan. ${ }^{2}$ Such was the perspective assumed - in opinions and actions against the Polish territorial aspirations in the post-War period - by the Anglo-Saxon leaders of the Entente, with the British Prime Minister, David Lloyd George, being most consistent in that respect (although the first one to point, back in 1916, to the geopolitical 'harm' of Poland's existence, if strong and independent from both of its great neighbours, was the foreign secretary, Arthur Balfour).

${ }^{2}$ G.F. Kennan, Russia and the West under Lenin and Stalin (Boston, 1960); H. Kissinger, Diplomacy (New York, 1993), pp. 241-245. 
The diplomatic efforts of Roman Dmowski and Ignacy Paderewski at the Paris Peace Conference, ${ }^{3}$ while on the other hand, the faits accomplis brought with the consecutive Polish uprisings: first in Wielkopolska (December 1918 - February 1919), and the three successive ones in Silesia (August 1919, August 1920 and May-June 1921), all had their influence on the final shape of the Polish-German border, countering the effects of the uncompromising will of the British prime minister, 'not to irritate the Germans' with territorial concessions to Poland. Nevertheless, Gdańsk, although it was within the borders of the First Polish Republic, was to be left out of the Second Republic, the plebiscites held in Warmia, Masuria and Powiśle brought the results much to Lloyd George's satisfaction - the disputed territories remained as part of Germany, while the Silesian plebiscite (and the third uprising) led to the partitioning of this territory, an act (much as the loss of the Pomeranian 'corridor' through the decision made at the Paris conference) to which Germany never consented. On those territories, the compromise was impossible. The calculations done in the name of the 'higher' European order, dictated that it could only be reached at the expense of the weaker - to appease the stronger.

The same principle formulated the point of departure for the political reflections by the victorious powers of the Entente concerning the border between Poland and Russia. The belief, so lively in 1919, that a non-Bolshevik, 'white' Russia would come to prevail, drove Paris to hold the same stance as London: not to accept any territorial changes, at the expense of Russia, that might reach beyond the borders of the Polish Kingdom, as delineated at the Congress of Vienna. A direct expression of that stance came with the declaration of the Supreme Allied Council on December 8, 1919, on the provisional eastern border of Poland, which was to pass from the northern part of Suvalki region, along the eastern border of the Białystok region and the Bug river, to the former border of the Polish Kingdom and Galicia, leaving out the territories of Małopolska. Although the declaration itself did not rule out the future Polish claims to the territories east of that borderline, it could be used (and later was used by Soviet diplomacy) as proof to the argument that such territorial claims were an evident expression of 'Polish imperialism'. When in July 1920, facing the Bolshevik

${ }^{3}$ K. Lundgreen-Nielsen, The Polish Problem at the Paris Peace Conference. A Study of the Policies of the Great Powers and the Poles, 1918-1919 (Odense, 1979). 
offensive, Poland had to request help from the western powers, the British foreign secretary, Lord George Curzon, sent a diplomatic note to the Commissar for Foreign Affairs, Georgy Chicherin, in which he extended southward the border delineated on December 8 , thus partitioning the Małopolska province with a line running east of the town of Przemyśl. That very line, drawn in fact by the secretary to Lloyd George, Philip Kerr, would make it into the pages of history under the name of the author of this diplomatic note - as the Curzon line. ${ }^{4}$ In a British diplomatic note, dated July 11, 1920 it was to designate the territories, the violation of which by Soviet Russia would result in some form of intervention by the Entente powers on behalf of Poland. In the course of World War Two, it acquired a much different meaning, justifying the partition concluded by the Soviet Union in collaboration with Hitler in September 1939 - along a similar line...

In the years 1919-1920, it was not the western powers that would play the decisive role in shaping the borders in the eastern part of the European continent. They would be settled through the interplay of power, interests, the political and social determination of the actors in that part of Europe, as well as ... the scope of political imagination of their elites. Poland and her political elites, assumed their part in the decisions being made (much to the irritation of the Western powers, unable to confine the country's role in that respect). Considering the pursuit of Polish 'eastern policy', the question of the possibility of reaching compromise in that area seems perhaps even more pressing than in analyzing Poland's relations with its southern neighbour. That very question left a painful mark on the history of the Polish-Lithuanian and Polish-Ukrainian conflict of the years 1918-1920. The answer most often offered to that question, and the perspective taken on that conflict, is inscribed in the two programmes, or rather two visions of the Polish eastern policy: the 'federalist' option associated with Józef Piłsudski, and the 'incorporationist' option of Roman Dmowski, with the former presented as carrying a possibility of compromise with Poland's neighbours to the East. It thus seems justified to consider the matter closely.

The idea of federalism, well grounded in the earlier concepts presented by Piłsudski in the years 1893-1905, practically delineated a programme of recovering those territories of the Polish

${ }^{4}$ R.H. Ullman, Anglo-Soviet Relations 1917-1921, vol. III: The Anglo-Soviet Accord (Princeton, 1972), pp. 153-155. 
Commonwealth, which fell prey to Russian take-over, and reconstructing - in the term proposed by Michał Römer, giving witness to those concepts - the Eastern Empire, grounded in the historical fundaments of the Grand Duchy of Lithuania. According to some, it was to take the form of a close Polish-Lithuanian (or LithuanianBelarusian) and Polish-Ukrainian federation, whereas according to others, including Römer himself, it was to be created with three, or perhaps four, entities, enjoying distinct statehoods: Poland, Ukraine, Lithuania, and potentially Belarus. ${ }^{5}$ Still other researchers point to the rather pragmatic approach presented by Piłsudski, his political realism and his ability to distance himself from all types of political doctrines, including federalism, which found its faithful supporters among a part of Marshal Piłsudski's entourage (Leon Wasilewski and Tadeusz Hołówko, among others). ${ }^{6}$ The Chief of State expressed his views most vividly in a letter to Leon Wasilewski, in April 1919, where he would write: 'I want to be neither an imperialist, nor a federalist, as long as I am unable to talk of those matters with some degree of seriousness - and a gun in my pocket.' The gun in the pocket, the accumulation of real power at his disposal, the policy of faits accomplis - such was the key objective in the efforts undertaken by Piłsudski, also in his eastern policy, which simply aimed at recreating and securing Poland's grandeur. ${ }^{7}$

Historical Lithuania (including Belarus) had a crucial significance in resolving the question of federalism. Ukraine, in turn, remained the touchstone for the issue of securing Poland from its great neighbour to the East, and for the possibility of establishing a new lasting order, a new strategic balance in the eastern part of Europe. Without Lithuania - with Vilnius as its capital - it was unfeasible to create a federation that would be grounded on the legacy of the Polish Commonwealth. Without a stable independence of the 30 millions of Ukrainians, it was unfeasible to contain the Russian or Bolshevik expansionism directed against the West. The former of the two problems, the rebirth of the tradition brought with the Grand Duchy of Lithuania, was undeniably close to Piłsudski's heart - the

${ }^{5}$ M. Römer, Józef Piłsudski, in: Lietuviu atgimimo istorijos studijos (hereafter-LAIS), vol. 3, Lietuvos valstybès ideja (Vilnius, 1991), pp. 460-461; a Polish translation: Niepodlegtość, 46 (1993), pp. 107-142.

${ }^{6}$ See a more detailed discussion of this debate in: A. Nowak, History and Geopolitics: A Contest for Eastern Europe (Warsaw, 2008), pp. 169-186.

${ }^{7}$ The letter to Leon Wasilewski quoted after: Józef Piłsudski, Pisma zbiorowe, V, ed. K. Świtalski (Warsaw, 1937), pp. 72-74. 
conscious heir to that tradition. The latter of the two, the Ukrainian problem, was primarily a question of purely strategic calculations.

On his return from a German prison to Warsaw in November 1918, Piłsudski did not step onto virgin territories in the relations between the newly recreated Poland, Ukraine and Russia. A PolishUkrainian war was de facto already being waged over Lwów/Lviv and the control of the whole eastern Galicia. The Bolsheviks were preparing for their great march West - onto the Lithuanian and Russian territories of the former Grand Duchy, and from there, through Poland, onto Germany. In turn, the politicians of the victorious Entente had no intention, for the time being, of forfeiting the recreation of non-Bolshevik Russia, thus willing to recognize Poland, or Finland, only within their ethnic borders. Pressed by the circumstances, commencing his task of steering the eastern policy of the reconstructed Poland, Piłsudski had to limit the scope of that policy to the very minimum: preparing the defence against Bolshevism, halting any definite settlements in relations with Ukraine, which might prevent a future compromise, while at the same time seeking conciliation, on terms acceptable to the Entente, with the rather obscure, although favoured by the Western powers, 'white Russia'.

That line of policy, intentionally founded on the programme proposed by the National Democrats and the Polish political representatives in Paris headed by that political faction, was clearly expressed in the instructions - which to this day have not been published as a whole - drafted by the head of state in November and December 1918 for his delegation to the Paris Conference, as well as for general Tadeusz Rozwadowski, the commander of the Polish Army on the Ukrainian front. In the instructions sent to Rozwadowski, Piłsudski pointed to the stance taken by the Entente, 'which according to all information to date, does not want to recognize Ukraine and wishes to treat the Ruthenian question as a Russian question'. Under the circumstances, he thus recommended a temporary, military occupation of eastern Galicia, which would allow to leave the political issues unsettled, for the time being. Those issues were to be discussed, in the words of Józef Piłsudski, when the situation becomes clear at 'the source of the Ruthenian [Ukrainian] question, that is in Kiev'. ${ }^{8}$ It was there, following the

${ }^{8}$ See a copy of Piłsudski's letter to general Tadeusz Rozwadowski, dated November 28, 1918, in: 'Papiery Aleksandra Kawałkowskiego', Biblioteka Polska in Paris, manuscript akc. 3505, vol. IV, doc. 392. 
collapse of the German-established hetmanate of Pavlo Skoropadskyi, that the decisive struggle would take place between the west-bound Bolshevik army, the Black Sea-based Russian Volunteer Army, and the inhabitants of those territories - the Ukrainians, with the supporters of the country's independence gathered around the Directorate and Symon Petlyura.

No one would still believe in the permanence of the Bolshevik rule in Eastern Europe, although the fear of their expansion, not only ideological but military as well, following the dissolution of the German Ober Ost, became a most real and well justified feeling at the turn of 1919. It was that very fear, reaching all the way to Paris, which Piłsudski - much as Roman Dmowski - aimed to benefit from, presenting Poland as a bulwark against that threat, thus assuring consent of the Entente powers for Poland's expansion beyond the minimum borders that were recognized by the West: beyond the borders of the Polish Kingdom of 1914. The line of argument assumed by Roman Dmowski, and presented to Piłsudski by Stanisław Grabski personally at the December 1918 meeting in the Belweder [the Palace of the head of state in Warsaw], was temporarily accepted by the head of state. He did not posses any real arguments, arguments of power, which would allow him to discard that line (he was still striving for the Western powers to recognize his position in Warsaw, while the Polish Army under his command remained inferior to the army of General Józef Haller, which was under the control of the Polish National Committee). In the instructions given to his delegation to the Paris Peace Conference, Piłsudski thus wrote:

On all matters pertaining to the eastern borderlands, from eastern Galicia to Lithuania, and on all matters related to Russia, a uniform direction must be pursued in conformity with that presented by the National Democrats. Efforts need to be made to explain to the Entente governments that Russia, having suffered from extensive and serious internal illness, will for a long time remain weak, ill, and with a demoralizing influence over the neighbours all around.

Yet the words of the instructions, in their part concerning 'the Ruthenian [Ukrainian] and Lithuanian questions', pointed to a much different, as compared to Roman Dmowski, balance in the vision of securing that eastward expansion, as held by Piłsudski. His representatives in Paris were 'to declare their support for an independent form of the Ukrainian statehood and to remain friendly and neutral, with regard to that newly founded state', recognizing, at 
the same time, the distinctiveness of Lithuanians, and undertaking to convince the latter of the benefits springing for them as well, from the revived tradition of the Grand Duchy of Lithuania. ${ }^{9}$

Thus, in one of the very first documents conveying the political thoughts of Józef Piłsudski, as head of state, the thoughts on the settlement of Polish eastern borders, two diverging concepts come to be presented in parallel: consenting to the incorporationist project developed by the National Democrats, as perhaps a less problematic fundament for compromise with the non-Bolshevik Russia, and her Entente supporters, while on the other hand - encouraging at least an attempt to use a broader diplomatic forum to present the idea of separating Russia and Poland with Ukrainian and Lithuanian (Lithuanian-Belarusian) statehoods, potentially in federation with Poland. Yet both of those seemingly divergent concepts intersected at a point marked by a conviction (common to Piłsudski and Dmowski), that between Russia and Germany there is no place for a weak Poland, confined to the minimum within her ethnic borders. When the vision of a federation of nations of the former Grand Duchy of Lithuanian would become completely unfeasible, the incorporationist concept could be pursued - as guaranteeing a particular security zone, safeguarding Poland against a threat from the East, thus offering an opportunity for development that would bring her a more equal competitive position, also vis-à-vis the defeated adversary to the West. Under unfavourable political circumstances, the idea of a federation was not to be opposed with the concept of incorporation. Such was the significance of the position held by Józef Piłsudski, as expressed vividly in February 1919 in the words addressed to his trusted envoy to Paris, Władysław Baranowski, and reiterated in December 1919, a fact which was noted by Kazimierz Świtalski (the head of state's assistant) in his Memoirs. ${ }^{10}$

A most explicit expression of the conviction held by Piłsudski, that the two perspectives are mutually complimentary in seeking practical concepts for the settlement of the eastern questions, is to be found in yet another instruction - dated November 30, 1918:

\footnotetext{
${ }^{9}$ Instructions of the head of state [Piłsudski] to his delegation for Paris Peace Conference, the instruction dated December 18/19, 1918, in: Archiwum Michała Mościckiego, vol. 3/4, manuscript No. 529, Józef Pilsduski Institute in New York.

${ }^{10}$ See: W. Baranowski, Rozmowy z Piłsudskim 1916-1931, ed. R. Świętek (Warsaw, 1990), p. 64; K. Świtalski, Diariusz 1919-1935, ed. A. Garlicki, R. Świętek (Warsaw, 1992), pp. 40-41.
} 
The borders of the future Poland need to secure her the capacity for eastward expansion [all emphases as in the original] and a full scope of colonization actions. Colonization in the East constitutes a necessary condition for the revival and growth of ruined industry, the only path to the employment of the unemployed masses, otherwise sentenced to forced emigration. $<\ldots>$ It needs to be stated that we seek good neighbourly relations with Russia. The friendly settlement of those relations is all the more easy since the expansion of both nations is directed eastward. Russia, ruined and exhausted with the loss of blood, is not able to return expansively to the West. Not taking away from Russia any of her own territories, and particularly any of her agricultural resources, Poland must properly secure territories for her own expansion, as well as to set a convenient and permanent state border in the East. That border should include Lithuania, the Pinsk region, the western part of Volhynia, and the industrial territories of central Galicia. Lithuania should be bound to Poland due to the need for colonization, common history, religious tradition, the memory of Uniates and finally due to the enormity of cultural effort, vested in her by Poles. $<\ldots>$ Yet in the end, should Lithuania as a whole remain outside of the Polish state and be attached to a different statehood, in such a case, Poland would have to insist that Lithuania proper be confined to her ethnic territory, without the regions of Belarusian Minsk and Polish Wilno. Polish influences in Lithuania are presently the sole social bulwark of that country against Bolshevism, and if we shall be restrained from establishing Lithuania as a rampart, the overflow of Bolshevism onto those territories shall be inescapable. In Galicia, our national minimum constitutes a line encompassing Lwów and Kalush; possibly, through a voluntary accord with Russia, we are prepared to make concessions in parts of eastern Galicia in return for Russian concessions on Lithuanian and Belarusian territories. Poland's eastern border must be straightened in agreement with Russia, giving Poland protection of the direct rail connection from Wilno, through Kowel to Lwów, while between Russia and Poland remain the marshes and forests bordering on the Pripyat river. The Pinsk region, wholly destroyed, constitutes the marshy border, a territory unfit for moving the large masses of soldiers. Poland's eastern rail line should pass through those territories, connecting Równo [sic] - Pinsk Wilno, at the very least Poland should hold in its control the rail connection of Drohobycz - Lwów - Kowel - Pinsk - Łuniniec - Baranowice - Wilno. With that, Russia is conceded all fertile territories, requiring no input or reconstructing work. We ourselves, in turn, take the destroyed regions, receptive to our strong colonizing material. ${ }^{11}$

The territorial programme presented in the above instruction, not diverging from the vision presented in parallel by Roman Dmowski at the meetings of the Polish National Committee, constituted a minimum, for which also Piłsudski was prepared to fight under any circumstances - so that a reconstructed Polish state could survive,

${ }^{11}$ Instructions of the Chief of State [Piłsudski] to his delegation for the Paris Peace Conference, the instruction dated November 30, 1918, in: Archiwum Michała Mościckiego, vol. 3/4, manuscript no. 210, Józef Piłsudski Institute in New York. For further analysis of these instructions, see: A. Nowak, Polska $i$ trzy Rosje. Studium polityki wschodniej Józefa Pitsudskiego (do kwietnia 1920 r.) (Cracow, 2001), chapter 2 . 
positioned between its powerful neighbours. Undeniably, a decisive majority of the Polish political opinion approved of that very programme. However, the head of state was not to resign from the more ambitious project of shattering the Russian Empire by sustaining an independent Ukraine, a project inspiring the political imagination for many a long year.

In the early months of 1919 , profiting from the military clash with the Bolsheviks on the Lithuanian-Belarusian front, as well as from the weakness of the presently dispersed holds of 'white' Russia, Piłsudski could pursue faits accomplis with respect to federation and recreation of the ties with historical Lithuania. He counted on convincing President Wilson to agree to that concept through the influence of Prime Minister Ignacy Paderewski, while at the same time assuring, at the very least, a desintéressement on the part of the British and the French, who had temporarily lost grounds for their hopes of reconstructing a strong, non-Bolshevik Russia.

However, Piłsudski proved ineffective in reasoning into the idea her principal and foremost recipients: the Lithuanians. He tried to reach them on the eve of his military effort, aimed at recovering Vilnius from the Soviets in April 1919. To carry out that mission, Michał Römer was sent in mid-April 1919 by the head of state to conduct secret talks with the key politicians of the already existing Lithuanian state in Kaunas. In the accounts of his fascinatingly astute reconnaissance of the political situation, Römer immediately conveyed, prior even to his mission to Vilnius, the essential difficulty inscribed in the concept developed by the head of state with regard to Lithuania:

First of all, Piłsudski would in effect be forced to pursue his Lithuanian policy with Polish means, primarily military, and thus with Polish blood. This single fact substantially precludes the opposition against his vision of Poland at any given stage of his actions. He would immediately be left without any means - in a vacuum. Second of all, he will not gain so easily the confidence and trust of the Lithuanians and Belarusians, as they will not credit their support for him, so important for the absolute freedom and agility in implementing those elements of the policy, which would at a certain point require the potential opposition against Poland. ${ }^{12}$

${ }^{12}$ M. Römer, Kulisy misji kowieńskiej (fragmenty Dziennika: wiosna 1919), ed. B. Makauskas, R. Miknys, Arcana, no. 70-71 (July-October 2006), a note dated March 19, 1919, p. 44; for further discussion of Römer and his mission in March 1919: Z. Solak, Między Polskq a Litwq. Życie i działalność Michała Römera 1880-1920 (Cracow, 2004), see esp. pp. 394-410. 
A crucial discussion took place on April 6, in Warsaw, between Piłsudski and Römer, in the course of which the head of state managed to convince the latter to undertake his difficult mission nevertheless. The exchange of arguments, which occurred during the talks, noted by Römer in its aftermath, constitutes one of the most reliable and insightful - yet unknown to this day - evidences to the political vision of Józef Piłsudski, on the eve of the grand design being turned into reality. It is those very notes (written down 2-3 days after the discussion), which are worth quoting at length:

Józef Piłsudski was better than others in understanding the importance of the stance, which the Lithuanians would assume with respect to his programme, and he was in full agreement with me that it is the Lithuanians who hold the key to the programme's success. Thus he was not surprised that I want to use that key to open the door, and that I make my access to the whole undertaking dependent on the Lithuanian support for the endeavour. $\langle\ldots>$ The Lithuanian Poles, where they are the strongest, in the Vilnius and Grodno regions, will have no motive for carrying through any federalist constructs, and will simply strive for incorporation into Poland, leaving ethnographic Lithuania to its own fate. Then, equally, the role of Polish landowner will be accentuated more strongly, finding no counteraction from a strong, democratic movement of the Lithuanians, able to change the balance in favour of Piłsudski's programme. The entire structure of that programme, social as much as political, will then collapse in a single act. A passive Belarusian mass will be unable to hold up the political shape of that construction. Piłsudski is well aware of those facts and is prepared for that possibility; for that reason he does not burn his bridges behind him, sparing the landowners in the first stage of his undertaking, as he well knows that if it should prove a failure due to the Lithuanians, there shall be no other way left but to assume the imperialist consequences of the Polish military effort, implementing the partition of Lithuania and annexing Vilnius to Poland, or alternatively, to conceit everything and withdraw from all participation in the settlement of the Lithuanian question. In such case, I will naturally choose the second option, fully refraining from partaking in the imperialist fragmentation of Lithuania, yet Piłsudski, who takes the command of the Polish forces, cannot withdraw and, should the unyielding stance of the Lithuanians prevent the fulfilment of Lithuania's programme for statehood, he shall assume the imperialist consequences. He has a full understanding of that fact and states it openly. In that respect, it seems that we are in agreement. ${ }^{13}$

Lithuanians proved themselves unyielding to the federalist concept: in the political realm, in Lithuania there was a clear domination of that perspective, which in Poland was represented by the course pursued by Roman Dmowski: the concept of building a nationstate. A moment of temporary hesitation in the course of the talks carried out in secrecy by Römer and the democratic ministers of

${ }^{13}$ Römer, Kulisy misji kowieńskiej, pp. 59-60 (a note dated April 9, 1919).

13 Ibid., pp. 67-74 (notes dated April 16-20, 1919). 
the Lithuanian government in Kaunas on April 16-17, was perhaps the sole instance, when a Polish-Lithuanian compromise might have appeared feasible.

When despite of the fiasco of the Römer mission, Piłsudski headed the Polish army into Vilnius - in spite of the federalist declarations being reiterated - that act marked the end for the hopes of a consensual delineation of the Polish-Lithuanian border. An open struggle began: over the capital of Lithuania, over a cultural and historical centre - for the Poles. The Lithuanians, in their vast majority, continued to hold the stance presented in a note written by their government on December 23, 1918, demanding that Poland recognize the sovereign Lithuania, with a capital in Vilnius. The Poles, in their vast majority, supported the resolution of the Constitutional Sejm, dated April 4, 1919, calling for 'a permanent unification with the Polish Republic of the Polish north-eastern provinces, with a capital in Vilnius'. A proclamation issued on April 22 by Piłsudski, on his arrival in Vilnius, now liberated from the Soviets - To the Citizens of the Former Grand Duchy of Lithuania - was no longer capable of rebuilding the union. ${ }^{14}$ A question remained open: how to dis-unite? The Lithuanians requested the Entente powers to intervene. On July 26, 1919, answering the request, Marshal Ferdinand Foch delineated the demarcation line between the Polish and the Lithuanian armies in the Suvalki region. The Foch line, as it turned out, was to draw the border over those territories permanently, although the fighting continued for over a year. In July 1920, The Lithuanians, aiming to recover Vilnius, turned to support the offensive of the Red Army against Poland, signing a treaty with Soviet Russia on July 12. When the Poles proved successful in fighting off the Red Army assault on Warsaw, a regular military conflict with Lithuania began - recovering Suwałki and Sejny for Poland,

${ }^{14}$ Piłsudski's proclamation To the Citizens of the Former Grand Duchy of Lithuania is to this day treated as a key document on the concept of federation as seen by the head of state. Having rid of 'the hostile Russian, German and Bolshevik violence' with the help of the Polish Army, the proclamation announced the introduction of a civil authority, whose aim was 'to facilitate the ability of the citizens to voice their opinion as to their fate and needs, through freely elected representatives'. See: Odezwa do mieszkańców bytego Wielkiego Księstwa Litewskiego, 22 IV 1919 r., in: J. Piłsudski, Pisma zbiorowe, vol. V, pp. 75-76; see: W. Suleja, 'Geneza odezwy Naczelnika Państwa do mieszkańców byłego Wielkiego Księstwa Litewskiego z kwietnia 1919 roku', Niepodległość, vol. XXIV (New York-London, 1992). 
thus approaching the Foch line. Following brief negotiations, the border was confirmed in a Polish-Lithuanian agreement of October 7, 1920. On that very day, a 14-thousand strong force commanded by general Lucjan Żeligowski, feigning insubordination with respect to the orders given by the Supreme Command of the Polish Army, began to prepare for a march on Vilnius, under Lithuanian control, as granted in the treaty with the Bolsheviks. An operation, to which Piłsudski agreed in fact, was an attempt at circumventing the diplomatic difficulties that would unquestionably arise in relations with the western powers, should a military effort at recovering Vilnius be officially approved. Two days later, General Żeligowski held the control over the disputed city. Oskar Milosz, on behalf of the Lithuanian government, was the person to file protests with the League of Nations against that military endeavour. The projected partition of Lithuania into autonomous cantons, as foreseen by the League, was rejected by both sides. In January 1922, the League resigned from any further mediation, and in March of that year, the Constitutional Sejm declared the assumption of state powers over the Vilnius territories by the Polish government. ${ }^{15}$

Force was also to be decisive in the parallel Polish-Ukrainian conflict, although a compromise on that front seemed - at least in theory - more likely, since the dispute did not formally span over the capital but only the peripheries of the two 'national territories'. Yet Lwów/Lviv and eastern Galicia were not just any peripheries: for the Ukrainian national movement, it constituted the territories where the movement could grow more freely and root itself more firmly - the loss of the city and the territories meant that the national effort for Ukrainian identity would have to be undertaken over the entire country. For Poland - Lwów/Lviv was the second, next to Warsaw, or perhaps due to a more embracing freedom under the Austrian partition - the primary capital of culture, the historical centre of Polish identity. Thus the conflict ensued immediately after the disintegration of the control over those territories, exerted by the Austrian rule (mediation). It was the Ukrainians who, on November 1, 1918, began by assuming control over Lwów/Lviv, and there proclaiming the sovereignty of the West Ukrainian People's Republic. A defence organized spontaneously by the local Poles was effective in opposing the Ukrainian endeavour. Poland, gradually - beginning

${ }^{15}$ For further discussion of Polish-Lithuanian relations in Polish historiography see: P. Łossowski, Konflikt polsko-litewski 1918-1920 (2nd ed. Warsaw, 1996). 
in mid-November - and according to its capacity, initiated military support for the compatriots defending Lwów/Lviv. The fight over the city turned into a regular Polish-Ukrainian war over eastern Galicia, a war, which by mid-1919, Poland had won. ${ }^{16}$

Attempting to go beyond the programme of annexing Ukraine, Piłsudski needed a much stronger military force than in the case of Vilnius operation in April 1919. In fact, he had to wait for the Polish victory over the Ukrainians in eastern Galicia - any other solution would have been rejected by a great majority of the Polish public opinion. Finally, he had to wait for the passing - in the period from summer to fall of 1919 - of the period of military successes of admiral Kolchak, and later general Denikin, which renewed the pressures exerted by the Entente powers in support of the reconstructed, allied Russian Empire (which naturally was to include the whole of Ukraine as its integral part).

In the spring of 1920, Piłsudski was finally ready to play his well-prepared Ukrainian card in the grand, strategic game for the future of the post-World War One Eastern Europe - not only against the Bolsheviks but against Russia as such. In that effort, he sought an agreement with the nations of the western okrainy of the empire, an agreement that would be effective, yet founded on terms proposed by Piłsudski, and on the Warsaw-Kiev alliance aimed at reconstructing Ukraine as a 'buffer between Poland and Russia'. Explaining the significance of that endeavour to the public opinion in Poland, a large part of which was unfavourable towards a prolonged war effort, Piłsudski invoked primarily the anti-Russian, and not anti-Bolshevik, arguments. Ukraine was to be a bulwark against Russian imperialism. ${ }^{17}$

An offensive against Kiev was to give Petlyura an opportunity to stabilize the Ukrainian statehood. The political implications of that offensive, without disclosing the most secret plans regarding Russia herself, were most clearly expressed by Piłsudski in his exposé to General Antoni Listowski, who was to take over the command of the Ukrainian front from the Marshal:

${ }^{16}$ See: M. Klimecki, Polsko-ukraińska wojna o Lwów $i$ Wschodniq Galicję 1918-1919 r. Aspekty polityczne $i$ wojskowe (Warsaw, 1997).

${ }^{17}$ The best introductions into details of Piłsudski's Ukrainian policy are: J.J. Bruski, Petlurowcy. Centrum Państwowe Ukraińskiej Republiki Ludowej na wychodźstwie (1919-1924) (Cracow, 2000), J. Pisuliński, Nie tylko Petlura. Kwestia ukrainska w polskiej polityce zagranicznej w latach 1918-1923 (Wrocław, 2004); T. Zarechka, Juzef Pilsudskii i Ukraina (Kiev, 2007). 
Marching into Ukraine, but only as far as the 1772 borders, we reject the Partition, and proclaim sovereignty over those territories, we thus correct the mistakes of our ancestors. We want to give [Ukraine] a chance for self-determination and rule by its own nation $<\ldots>$ I played the card, pursuing the final stake, to do something for the future of Poland, at least in such a way, to weaken the power of the future, great Russia, and should it succeed, to help create Ukraine $<\ldots>$ But the core of the problem is whether that Ukraine will rise, does it have enough strength and people to create and organize itself, since we cannot stay here permanently. <.. > I cannot recreate the borders from 1772, as I once desired, Poland does not want those borderlands, Poland does not want to carry the burden, all parties have clearly voiced their views, we do not want to bear the costs, nor give anything... and without the efforts, the sacrifices, nothing can be created! Thus there is no other way - but to attempt to create a sovereign Ukraine. Petlyura plays no role in that, he is a tool, nothing more. And should it not succeed, we shall leave that chaos to its own fate. Let it fall, digest itself, ruin, weaken, eat away...In such a state it will not be a threat to us for many years! And beyond that... future will show! ${ }^{18}$

If Ukraine under Petlyura had held for at least the summer of 1920, Piłsudski would have been able to think of the somewhat enigmatically termed 'final act', referred to in the letter to General Kazimierz Sosnkowski, or perhaps rather an epilogue of the great eastern politics, with the Belarusian or joint Belarusian and Russian formation, under Stanisław Bulak-Balakhovich, playing a key part. ${ }^{19}$ Counting on an internal decomposition in Soviet Russia, prompted by a prestigious defeat and the lack of supplies of Ukrainian grain (and perhaps coal as well), Piłsudski could have attempted to pursue one of the pre-planned paths to the crowning achievement of his eastern politics: most probably under the banners of the 'third Russia' concept of Boris Savinkov, or of Belarus (with the participation of the Balakhovich formation), and the following unification of the territories belonging to the old Grand Duchy of Lithuania, federated with Poland. ${ }^{20}$

18 Antoni Listowski, Dziennik, vol. 3, Biblioteka Czartoryskich, Ew. 2988, pp. 185 i $215-216$; the quoted passage has been already published in: A. Nowak, 'Rozmowy z Józefem Piłsudskim. Z Dziennika gen. Antoniego Listowskiego', Arcana, no. 23 (5/1998), pp. 42, 43-44.

${ }^{19}$ On Belarusian side of Piłsudski's plans and on Stanisław Bułak-Bałachowicz see: M. Cabanowski, Generat Stanisław Bułak-Bałachowicz. Zapomniany bohater (Warsaw, 1993); K. Gomółka, Między Polska a Rosja. Białorus w koncepcajch polskich ugrupowań politycznych 1918-1922 (Warsaw, 1994); Z. Karpus, Wschodni sojusznicy Polski w wojnie 1920 roku (Toruń, 1999).

${ }^{20}$ Piłsudski to K. Sosnkowski, May 6, 1920 , in: Listy Józefa Piłsudskiego, ed. K. Świtalski, Niepodległość, vol. VII (London-New York, 1962), pp. 114115; for a broader perspective on this concept see: Nowak, Polska i trzy Rosje, pp. $458-501$. 
Military miscalculations, a Soviet strike to the north, and most of all, lack of any significant support on the part of the Ukrainian people for yet another attempt at building their statehood anew with foreign bayonets, and finally the actual lack of determination (and perhaps simply of will) on the part of Polish society to carry through Piłsudski's semi-clandestinely prepared plan of a grand eastern strategy - all that played its part in the failure of that plan. In July 1920, with apparent irritation, Piłsudski concluded that the Ukrainians themselves should proceed with faits accomplis, as Poland was unable to continue its engagement in the military support for Petlyura against the European public opinion. This marked the return to the minimum option of defending the territories separating the Bolshevik Russia from the centres of Polish national life.

The advocates of the thesis on Piłsudski's devotion to the ideals of federalism, as well as the fight for our freedom and yours, point to the interpretations of the Riga peace talks, as their last line of defence. According to this thesis, well rooted in the historiography, and particularly in journalist writing - Piłsudski wanted to revive his federationist programme and the war with the Bolsheviks over it. Distinguished experts on this subject, Janusz Cisek and Włodzimierz Suleja, come to claim that 'in fall of 1920, Piłsudski did not yet abandon his far-reaching idea of binding Poland, Ukraine and Belarus with a real bond of federation, and under exceptionally favourable conditions, encompassing Latvia as well'. ${ }^{21}$ A stop to this, was to be put by a 'treason' against his programme, committed in Riga by the representatives of the Sejm participating in the delegation sent to proceed with the peace talks (headed by Stanisław Grabski of the National Democrats).

Nevertheless, this approach has recently been challenged by historians investigating anew the details of the negotiations in Riga. In an article treating the issue of Ukraine in the political actions of Roman Knoll, a young researcher from Rzeszów, Jan Pisuliński, points out the fact that this trusted associate of Piłsudski, and one of the most devoted supporters of the anti-Russian alliance with Petlyura, came to change his stance completely during the talks in Riga, where he was the secretary general of the Polish delegation. In a secret instruction, he proposed that the Polish side should resign from supporting Petlyura's political circles during the negotiations,

${ }^{21}$ J. Cisek, W. Suleja, 'Ignacy Matuszewski w rokowaniach ryskich': Traktat ryski 1921 r. Po 75 latach, ed. M. Wojciechowski (Toruń, 1998), p. 78. 
and instead stress the necessity of upholding at least a formal sovereignty of the Soviet Ukraine from Moscow. Since Petlyura did not manage to remove the Bolshevik government of Krystian Rakovski from Kiev, perhaps in the future it would be the Ukrainian communists who, if upholding even the formal sovereignty of their state from Soviet Russia would be possible, should oppose their 'older brothers' from Moscow? ${ }^{22}$ Well, this very hope, that was to justify abandoning the Ukrainian People's Republic in Riga, was to come true, but 70 years later...

There seems to be no document giving record to the possible objections voiced by Piłsudski in face of the territorial decisions being made in Riga: decisions of a de facto partition of Ukraine and Belarus between Poland and Soviet Russia. Undoubtedly, Piłsudski knew that the decision on the renouncement of Minsk was not made exclusively by Stanisław Grabski, but rather was a result of cooperation between the leader of the National Democracy and a representative of the Polish Socialist Party in Riga - Norbert Barlicki. It was both of them, together with Władysław Kiernik of the Polish Peasant Party - Piast, who successfully advocated the exchange of Minsk for a strategic corridor separating Soviet Russia from Lithuania, which effected in Poland bordering Latvia. It seems that such an exchange was more in line with the attitude of Piłsudski towards the matter, seeking strategic facts, rather than with the stance held by Leon Wasilewski and Feliks Perl, opposing the surrender of Minsk with the aim of seeing the capital of Belarus perform as a centre, attracting the pro-Polish independence movement. ${ }^{23}$

Piłsudski did not protest against the provisions of the Peace of Riga, as he well understood that there shall be no social consent to continuing the war. He witnessed the defeat of his own grand plans, that could have taken the shape of a federation. As Michat Sokolnicki, one of the most trusted co-authors of marshal's policies towards the East, recalls, prior to the signing of the Peace of Riga, Piłsudski formulated his propositions in the following words:

22 J. Pisuliński, 'Kwestia ukraińska w działalności Romana Knolla', Ukraina a Polska. Partnerstwo strategiczne na przełomie tysiacleci, part 1, ed. V.I. Serhijchuk (Kiev, 2001), p. 244.

${ }^{23}$ R. Bäcker, 'PPS wobec Traktatu Ryskiego', Traktat ryski, pp. 73-85; the most detailed analysis of Riga negotiations is to be found in: J. Borzęcki, 'Niełatwy kompromis: granica ryska w świetle rokowań w Mińsku i Rydze', part I, Arcana, no. 58-59 (4-5/2004), pp. 73-92; part II, Arcana, no. 61-62 (1-2/2005), pp. 213-249. See also: J. Borzecki, The Soviet-Polish Peace of 1921 and the Creation of Interwar Europe (New Haven, 2008). 
The fundament of the strategic defence of the state, should be the Pinsk marshes $<\ldots>$ The future borderline must give Poles the option of a castling move, thus the line through the town of Łuniniec; Poland should not extend all the way to Minsk, encompassing only the ethnically mixed [!] Russo-Polish-Lithuanian provinces, without the number or cultural advantage of foreign population; finally in the Volhynia, only what is necessary for the communication with Eastern Małopolska. $<\ldots>$ I do not want to create, between Poland and Russia, any border issues contestable in the future... ${ }^{24}$

Was that a cynical betrayal of Piłsudski's own programme? It was rather an unavoidable consequence of its defeat in 1920. At last, it is worth considering the reasons behind the defeat. Although it was grounded on the 200 years old tradition in Polish conceptions of disintegrating the Russian empire with the force of the nations confined within its boundaries, the strategy implemented by Piłsudski in 1920 was in fact a second practical attempt, following the German efforts, of finding an alternative to the Russian domination over the Intermarum between the Baltic and the Black Sea. Lithuanians and Ukrainians - the principal potential partners to this strategy found themselves in the state of open war with Poland over the borderlines, already at the moment when practical decisions on the strategy were being taken. Quite clearly, this did not facilitate common understanding. Moreover, the tradition of the Polish Commonwealth itself, turned out to be more of a barrier than a help in establishing confidence as to the intentions of Piłsudski's plans. Finally, Poland, quite differently from the German Empire some years earlier, did not command respect with its military capabilities, or economic potential. Rather, Piłsudski was taking advantage of a particular power vacuum, left after the First World War in Eastern Europe from the civil war in Russia.

The phantom of Pax Polonica disappeared before the Peace of Riga was even signed. Thus, we shall never know how it would work in practice. Piłsudski was forced to abandon his dreams of a geostrategic revolution in Eastern Europe. He would say that what he needed were men, who could make something out of nothing and the impossible possible. He found only too few of them. He did not win the confidence, or perhaps differently - did not break the feeling of distrust - of those, on whose participation depended the success of his plans: the nations of the old Commonwealth. Ukrainian historian and essayist, Ivan Lysiak-Rudnyćkyj, called

${ }^{24}$ M. Sokolnicki, 'Józef Piłsudski a zagadnienie Rosji', Niepodległość, 2 (London, 1950), p. 65. 
Piłsudski the epigone of that Respublica, which had already been dead in the twentieth century, and which he perceived primarily as a tool of Polish rule over Lithuanians, Belarusians and Ukrainians. ${ }^{25}$ Such a perception of Piłsudski, and Poland for which he stood, proved for the Ukrainians, Belarusians and Lithuanians of 1920, to be a self-fulfilling prophecy.

A similar role, although on a greater scale, was played by the assessment of the Polish policies towards the East, formulated by the leading politicians of the victorious powers in the Entente, especially of both anglophone powers. This assessment can be summarized as follows: a revived Poland, a product of goodwill on the part of the Entente, showed under the rule of Piłsudski, unrestrained imperial ambitions towards the East, expanding beyond the borders of the old Congress Poland, beyond the Bug River line, which Russia (any Russia) could come to accept. Only a feeble Poland, with no conflicts over borderlines with its great neighbours, could find a stable place on the map of Europe. Unwilling to accept such a place and such a verdict, Piłsudski essentially started a war with Russia, leading to a situation, where the stability of not only Poland, but the whole Versailles system was put at risk, by alienating from it two great powers - the stability of not only Germany, but Russia as well. In this respect, Piłsudski was to betray the greater interest, or the right to general order and international stability, and all that in the name of narrowly defined national interest of Poland, understood in terms of territorial gains in the East. In this line of reasoning, present - as was previously mentioned - in Western historiography to this very day, the policies that Piłsudski stood for, referred to as the Polish 'imperialism of weakness', come to serve the purpose of a scapegoat, bearing the blame for the break-up of the Versailles order and consequently for driving Europe into a new war: a war that was a reprisal not only for the First World War, but for the defeat of the Red Army in the war of 1920 as well. In that sense, Poland served the purpose of a scapegoat also in reality, paying for that given role the highest of prices - on 1 and 17 September 1939.

We will not know what would the political, social, economic and cultural relations between the nations of Eastern Europe have been like, should Poland have triumphed in 1920, and witnessed on the Dnieper River, the establishment of the Petlyura government,

${ }^{25}$ I. Łysjak-Rudnyćkyj, Istorichni ese, vol. 1 (Kiev, 1994), pp. 101-102. 
on the Neris and Nemunas Rivers - the supporters of renewing the bonds between the old Grand Duchy of Lithuania and the Crown, and consequently of forcing Moscow (and the Western powers with it) to accept the new order. We shall never know, if it would have been an order, as imperial in nature, as that under the domination of the Romanov dynasty in this region, or that under the project of Mitteleuropa proposed by Generals Hoffmann and Ludendorff, expanded onto this region, or finally, that of the Soviet empire. We shall never know, as there has never been a Polish empire, nor a federation of Eastern European nations, framed by Poland.

The results of the Polish Army operational success against the invading Red Army in August and September 1920 spared most of the newly created east and central European states from the fate of the Soviet republics - for the next 20 years at least. But Piłsudski's political defeat was obvious: Poland did not form any counterweight, to either Russian or German power. Instead of a federation or at least a close alliance with nations of the old Commonwealth, Poland was forced to make a new agreement with Russia - Bolshevik this time - to partition Ukraine and the territories of the old Grand Duchy of Lithuania. This failure was the result of the lack of really popular partners for Piłsudski's policy in Ukraine and Lithuania, and of Poland's relative military and economic weakness - relative, that is, to the great task of constructing and supporting a new independent power between Germany and Russia.

Modern nationalism triumphed - in Poland too. The truncated territory of the old Commonwealth - transformed into the Second Polish Republic - was to be treated for most of its existence as an ethnic Polish state in the making. This was treated however, at the same time, by its Piłsudski-ite elites at least, as a mini-empire, a regional power, struggling against its two powerful neighbours and their revisionist ambitions. If there was anyone approximating to the rank of emperor in contemporary Polish history - Piłsudski came the closest to that title: in personality, scope of his power (after the coup in 1926), and his ideology: statist and supra-national rather than narrowly nationalistic. ${ }^{26}$

${ }^{26}$ See an interesting discussion of this point: T. Snyder, The Reconstruction of Nations. Poland, Ukraine, Lithuania, Belarus, 1569-1999 (New Haven-London, 2003), pp. 57-65; cf: A. Nowak, 'Between Imperial Temptation and Anti-Imperial Function in Eastern European Politics: Poland from the Eighteenth to Twenty-first Century', in: Emerging Meso-Areas in the Former Socialist Countries: Histories Revived or Improvised, ed. K. Matsuzato (Sapporo, 2005), pp. 247-284. 
Author Details

Andrzej Nowak, professor in the Institute of History, of the Jagiellonian University Cracow, and in the Institute of History, Polish Academy of Sciences (Head of Eastern European History Section); editor-in-chief of the politico-cultural magazine Arcana. His professional interests cover Soviet and East European modern history; political philosophy; contemporary theories of empire and nation; geopolitics; modern massmedia. He is author and editor of 12 books, among them: History and Geopolitics: A Contest for Eastern Europe (2008); Historie politycznych tradycji: Pitsudski, Putin i inni (2007); Russia and Eastern Europe: applied 'imperiology' (2006)

Email: chlapnowak@neostrada.pl

\author{
ATGIMUSI LENKIJA AR REKONSTRUOTA IMPERIJA? \\ KLAUSIMAI DĖL LENKIJOS VYKDYTOS \\ RYTU POLITIKOS KURSO IR JOS REZUTATU 1918-1921 M.
}

Santrauka

ANDRZEJ NOWAK

Straipsnyje pateikiamos Lenkijos užsienio politikos ir karinès strategijos 19181921 m. pagrindinès geopolitinès koncepcijos. Autorius aptaria dvi bendras Lenkijos vykdytas politikos programas Rytų kaimynių atžvilgiu: „federalizmą”, siejamą su Józefu Piłsudskiu, ir Romano Dmowskio propaguotą ,inkorporacionizmą“ (angl. incorporationist option). Daugiausia analizuojamos pastangos igyvendinti pirmają programą. Iš pradžių detaliai analizuojami Piłsudskio nurodymai lenkų delegacijai Paryžiaus taikos konferencijoje 1918 m. pabaigoje, išsiųsto i Lietuvą 1919 m. balandị su specialia misija Michało Römerio nesėkmès ir jo misijos žlugimo priežastys. Autorius atkreipia dèmesi $i$ istoriją, susijusią su „Ukrainos korta“, kuria sužaidè Piłsudskis 1919 ir 1920 m. tam, kad būtų sudaryta geopolitinè atsvara bet kokiam Rusijos/Sovietų imperializmui. Be to, straipsnyje įvertinama Piłsudskio vykdytos Rytu politikos, kaip vieno pagrindinių veiksnių, dvidešimčiai metų sustabdžiusių Sovietų Rusijos planus skverbtis giliau i Vakarus, reikšmè. 